\title{
Biosorption of cadmium by Fucus spiralis
}

Bruno Cordero, Pablo Lodeiro, Roberto Herrero, Manuel Esteban Sastre de Vicente*

Departamento de Química Física e Enxeñería Química I, University of A Coruña, Alejandro de la Sota 1, 15008 A Coruña, Spain.

Corresponding author e-mail: eman@udc.es; Phone: (34) 981167000 Fax: (34) 981167065

Cadmium biosorption properties of nonliving, dried brown marine macroalga Fucus spiralis from Galician coast (NW Spain) have been investigated. The biosorption capacity of the alga strongly depends on solution $\mathrm{pH}$, being the uptake almost negligible at $\mathrm{pH} \leq 2$ and reaching a plateau at around $\mathrm{pH}$ 4.0. Cadmium biosorption kinetics by Fucus spiralis is relatively fast, with $90 \%$ of total adsorption taking place in less than one hour. A pseudosecond order mechanism has been proved to be able to predict the kinetic behavior of the biosorption process. The effect of initial cadmium ion concentration, alga dose, $\mathrm{pH}$ of the solution and temperature on the biosorption kinetics has been studied. The Langmuir, Freundlich, Langmuir-Freundlich and Tóth isotherms were used to fit the experimental data and to find out the adsorption parameters. Acid-base properties of the alga have been studied potentiometrically, in order to calculate the number of acidic groups and the apparent $\mathrm{pK}$ value by using Katchalsky model. The $\mathrm{pK}$ obtained is comparable with typical values associated to the ionization of carboxyl groups of alginates supporting the implication of these groups in the biosorption process.

Keywords: Biosorption, biotechnology, cadmium, marine algae.

\section{INTRODUCTION}


Cadmium, lead and mercury are the heavy metals with the greatest potential hazard to humans and environment. Cadmium, which is widely used, has been well recognized as a very toxic heavy metal for its negative effect on the environment where it accumulates throughout the food chain, posing a serious threat to human health. The main anthropogenic pathway through which cadmium enters the environment is via waste from a wide variety of industrial processes such as electroplating, plastics manufacturing, mining, paint pigments, alloy preparation, silver-cadmium batteries and metallurgical processes. ${ }^{[1,2]}$

At present, there are a number of different conventional methods for the removal of heavy metal pollutants from wastewaters when they are present at high concentrations. These technologies may be ineffective or expensive when heavy metals are present in wastewater at low concentrations (from 1 to $100 \mathrm{mg} \cdot \mathrm{L}^{-1}$ of dissolved metal), or when a very low concentration of heavy metal is required. ${ }^{[3]}$

For these reasons, in the last decade, alternative metal removal and/or recovery methods for treating wastewaters containing low levels of heavy metals are being considered. All these methods are based on metal-sequestering properties of certain natural materials of biological origin. Biosorption uses the ability of certain types of biological materials to retain relatively high quantities of metal ions by "passive" sorption and/or complexation.

Abundant natural materials have been suggested as potential biosorbent for heavy metals. ${ }^{[4]}$ Numerous chemical groups have been suggested to contribute to biosorption metal binding by either whole organisms such as algae and bacteria, or biopolymers. ${ }^{[5]}$ Among the suggested groups, it can be mentioned carboxyl, hydroxyl, carbonyl, sulfhydryl, thioether, sulfonate, amine, imine, amide, imidazole, phosphonate, and phosphodiester groups. The role that any given group of the biomass plays depends on factors such as: the number of sites in the biosorbent material, its accessibility, its chemical state (i.e. availability), and the affinity between site and metal (i.e. binding strength). ${ }^{[6]}$ 
The main components responsible for metal biosorption in marine algae are the alginate, which is present in a gel form in their cell walls, and fucoidan. ${ }^{[6]}$ Marine algae contain a high proportion of alginate, constituting $10-40 \%$ of the dry weight of the biomass. ${ }^{[7]}$ Carboxylate groups of alginate have been identified as the main metal binding sites. Other negatively charged functional groups such as the sulphonate groups of fucoidan also contribute to heavy metal complexation. ${ }^{[8]}$ However, it is difficult to evaluate the absolute role that these polymers play in determining the heavy metal uptake. ${ }^{[6]}$

The present work reports the study of the biosorption kinetics and the biosorption equilibrium of cadmium by Fucus spiralis collected from the Galician coast (NW Spain). In the biosorption kinetics the effects of initial cadmium ion concentration, alga dose, $\mathrm{pH}$ of the solution and temperature have been analyzed. Several kinetics models like pseudo-first-order, diffusion, pseudo-second-order and Elovich equation ${ }^{[9-11]}$ have been tested. The acid-base properties of this alga have also been studied, as they are related to their capacity of binding heavy metals. The Katchalsky model was employed to obtain the apparent pK value of carboxyl groups from the alga. Moreover, the equilibrium adsorption isotherms of Langmuir, Freundlich, Langmuir-Freundlich and Tóth, were obtained for the quantitative description of the cadmium uptake.

\section{EXPERIMENTAL}

\section{Materials}

Samples of brown marine alga Fucus spiralis were collected from the coast of A Coruña (Galicia, NW Spain). The alga was washed twice with running water and once with deonized water. After washing, it was oven-dried at $60{ }^{\circ} \mathrm{C}$ for 24 hours, crushed with an analytical mill (IKA A 10), sieved (size fraction of 0.5-1 mm) and stored in polyethylene bottles until use. 


\section{Chemicals}

Chemicals used in this work were $\mathrm{HNO}_{3}$ (Merck suprapur and Merck pro analysis), $\mathrm{NaNO}_{3}$ (Merck pro analysis), $\mathrm{Cd}\left(\mathrm{NO}_{3}\right)_{2} \cdot 4 \mathrm{H}_{2} \mathrm{O}$ (Merck pro analysis), cadmium atomic absorption standard solution $\left(1.000 \pm 0.002 \mathrm{~g} \cdot \mathrm{L}^{-1}\right)$ (Panreac), $\mathrm{NaOH}$ (Merck pro analysis), $\mathrm{HCl}$ (Merck pro analysis), $\mathrm{N}_{2} \mathrm{C}-55$ from Carburos Metalicos and cellulose nitrate membrane filters (Whatman and Albet).

\section{Methods}

\section{Kinetic studies}

In the kinetic studies, ionic strength was adjusted to $0.05 \mathrm{M}$ with $\mathrm{NaNO}_{3}$ and cadmium concentration was analyzed with a cadmium ion selective electrode (CdISE) previously calibrated in cadmium concentration. This technique allows a great number of experimental points to be obtained easily and quickly without need to withdrawn solution for the measurements. All the experiences were done at least in duplicate.

Effect of $\mathrm{pH}$ of the solution: A sample of $0.25 \mathrm{~g}$ of alga was added to $100 \mathrm{~mL}$ of cadmium solution $\left(250 \mathrm{mg} \cdot \mathrm{L}^{-1}\right)$ at constant temperature $\left(25.0 \pm 0.1{ }^{\circ} \mathrm{C}\right)$. The experiments were carried out at $\mathrm{pH} 3.5,4,4.5,5,5.5,6$ and 6.5, using $\mathrm{HNO}_{3}$ instead of $\mathrm{HCl}$ for $\mathrm{pH}$ adjustment in order to avoid cadmium-chloride complexation, since the CdISE responds to free cadmium ions. The following kinetics experiments were done at natural $\mathrm{pH}$ of the metalalga solution, which correspond to a value between 5 and 5.5 for any experimental conditions.

Effect of initial metal concentration: A sample of $0.25 \mathrm{~g}$ of alga was added to $100 \mathrm{~mL}$ of cadmium solution at constant temperature $\left(25.0 \pm 0.1{ }^{\circ} \mathrm{C}\right)$ and natural $\mathrm{pH}$. The initial concentrations of metal solution tested were $10,50,100$ and $250 \mathrm{mg} \cdot \mathrm{L}^{-1}$.

Effect of alga dose: Samples of 0.1, 0.25, 0.5 and $1 \mathrm{~g}$ of alga were added to $100 \mathrm{~mL}$ of cadmium solution $\left(250 \mathrm{mg} \cdot \mathrm{L}^{-1}\right)$ at constant temperature $\left(25.0 \pm 0.1^{\circ} \mathrm{C}\right)$ and natural $\mathrm{pH}$. 
Effect of temperature: A sample of $0.25 \mathrm{~g}$ of alga was added to $100 \mathrm{~mL}$ of cadmium solution $\left(250 \mathrm{mg} \cdot \mathrm{L}^{-1}\right)$ at natural $\mathrm{pH}$. The experiments were carried out at 15.0, 25.0, 35.0 and $45.0 \pm 0.1^{\circ} \mathrm{C}$ in a constant temperature shaker bath.

\section{Potentiometric titrations}

The algal biomass employed for potentiometric titrations was previously protonated by a two steps acid treatment. The treatment was carried out by soaking twice the biomass in a $0.1 \mathrm{M} \mathrm{HCl}$ solution at a 1:50 and a 1:200 $\left(\mathrm{w} \cdot \mathrm{v}^{-1}\right)$ ratio with regular shaking on a rotary shaker at $175 \mathrm{rpm}$ for 3 hours. Afterwards, the biomass was rinsed thoroughly with deionized water until constant conductivity was achieved. Finally, it was dried in an oven at $60^{\circ} \mathrm{C}$ overnight.

The alga was titrated at constant temperature $\left(25.0 \pm 0.1^{\circ} \mathrm{C}\right)$ with an automatic burette CRISON model BU 1S connected to a Hamilton syringe $(10 \mathrm{~mL})$ and to a Crison micropH 2000 meter equipped with a Radiometer GK2401C combination glass electrode ( $\mathrm{Ag} / \mathrm{AgCl}$ sat. as reference). The glass electrode was calibrated in solutions of known proton concentration at a constant ionic strength following the procedure described elsewhere. ${ }^{[12,13]}$

For potentiometric titration, $0.5 \mathrm{~g}$ of dry protonated biomass was suspended in a 0.05 $\mathrm{M} \mathrm{NaNO}_{3}$ solution $(100 \mathrm{~mL})$ and accurate volumes of $0.05 \mathrm{M} \mathrm{NaOH}$ were added stepwise. The suspension was shaken and purged continually with a nitrogen stream to remove $\mathrm{O}_{2}$ and $\mathrm{CO}_{2}$. The experience was done in duplicate.

\section{Equilibrium studies}

Eight cadmium(II) solutions were prepared by dissolving $\mathrm{Cd}\left(\mathrm{NO}_{3}\right)_{2} \cdot 4 \mathrm{H}_{2} \mathrm{O}$ in deionized water, with concentrations between 10 and $350 \mathrm{mg} \cdot \mathrm{L}^{-1} .40 \mathrm{~mL}$ of each solution were placed in $100 \mathrm{~mL}$ Erlenmeyer flasks containing $0.1 \mathrm{~g}$ of alga with particle size $0.5-1$ $\mathrm{mm}$. The mixtures were agitated on a rotary shaker at $175 \mathrm{rpm}$ for 4 hours, until equilibrium was reached. $\mathrm{NaOH}$ and $\mathrm{HNO}_{3}$ were used for $\mathrm{pH}$ adjustment. After shaking the flasks, the 
algal biomass was filtered through a $0.45 \mu \mathrm{m}$ pore size cellulose nitrate membrane filter and the filtrate was analyzed for the remaining cadmium ion concentration by differential pulse anodic stripping voltammetry (DPASV), by use of 757 VA Computrace (Metrohm) with a conventional system of three electrodes: hanging mercury drop electrode as working electrode, $\mathrm{Pt}$ auxiliary electrode and $3 \mathrm{M} \mathrm{Ag} / \mathrm{AgCl}$ as reference electrode. Adsorption isotherms were determined at $\mathrm{pH} 4.5 \pm 0.1$. Moreover, the effect of $\mathrm{pH}$ on cadmium uptake has been also studied. All the experiences were done at least in duplicate.

\section{RESULTS AND DISCUSSION}

\section{Kinetic studies}

In order to investigate the mechanism of biosorption of cadmium by the alga Fucus spiralis and the potential rate controlling steps such as mass transport and chemical reactions processes, kinetic models have been used to test experimental data. These kinetic models included diffusion, pseudo-first order, pseudo-second order and Elovich equation. ${ }^{[9-11]}$

Elovich, first order and diffusion models only achieved a good fitting for the first minutes of experimental data (not shown). The best fits, in the whole data range, were found with a pseudo-second order model, indicating that the rate-limiting step is a chemical biosorption process between cadmium and alga. Similar conclusions were found by Ho and McKay as a result of an analysis of data from the literature. They reported that most of the sorption systems follow a pseudo-second order kinetic model. ${ }^{[14]}$ However, the fact that experimental data may be fitted by a given rate expression is not sufficient evidence that the molecularity of the reaction is that implied by the rate expression. The kinetic rate equation of the pseudo-second order chemical sorption process was proposed by $\mathrm{Ho}^{[11,15]}$ and is given by

$$
\frac{\mathrm{dq}_{\mathrm{t}}}{\mathrm{dt}}=\mathrm{k} \cdot\left(\mathrm{q}_{\mathrm{e}}-\mathrm{q}_{\mathrm{t}}\right)^{2}
$$


where $k\left(\mathrm{~g} \cdot \mathrm{mg}^{-1} \cdot \mathrm{min}^{-1}\right)$ is the pseudo-second order constant of sorption, $q_{e}\left(\mathrm{mg} \cdot \mathrm{g}^{-1}\right)$ is the cadmium ion sorbed at equilibrium, represents the metal uptake and is given by Equation (2), and $q_{t}$ is the amount of cadmium ion adsorbed at any time, $t$ (min).

$$
\mathrm{q}_{\mathrm{e}}=\frac{\mathrm{V} \cdot\left(\mathrm{C}_{\mathrm{i}}-\mathrm{C}\right)}{1000 \cdot \mathrm{W}}
$$

where $V$ is the volume of cadmium solution $(\mathrm{mL}), C_{i}$ and $C$ are the initial and equilibrium concentration of cadmium in the solution $\left(\mathrm{mg} \cdot \mathrm{L}^{-1}\right)$ respectively, and $w$ is the mass of alga $(\mathrm{g})$.

Separating variables in Equation (1) and integrating for the boundary conditions $q_{t}=0$ at $t=0$ and $q_{t}$ at time $t$, the following equation is obtained:

$$
\mathrm{q}_{\mathrm{t}}=\frac{\mathrm{q}_{\mathrm{e}}^{2} \mathrm{k} \cdot \mathrm{t}}{1+\mathrm{q}_{\mathrm{e}} \mathrm{k} \cdot \mathrm{t}}
$$

which can be linearized to the following equation

$$
\frac{\mathrm{t}}{\mathrm{q}_{\mathrm{t}}}=\frac{1}{\mathrm{k} \cdot \mathrm{q}_{\mathrm{e}}^{2}}+\frac{1}{\mathrm{q}_{\mathrm{e}}} \cdot \mathrm{t}
$$

The equilibrium biosorption capacity, $q_{e}$, and the pseudo-second order rate constant, $k$, were experimentally determined from slope and intercept of straight-line plots of $t / q_{t}$ against $t$.

\section{Effect of $p H$ of the solution}

The results of the effect of solution $\mathrm{pH}$ on kinetic experiments carried out using an initial cadmium concentration of $250 \mathrm{mg} \cdot \mathrm{L}^{-1}$, temperature of $25 \pm 0.1^{\circ} \mathrm{C}$ and alga dose of 2.5 $\mathrm{g} \cdot \mathrm{L}^{-1}$ are shown in Figure 1. The values of $k, q_{e}$ and the coefficients of correlation, $r^{2}$ at several $\mathrm{pH}$ values of cadmium solutions are listed in Table 1. These are average values estimated from the different experiences with the corresponding fitting errors.

The biosorption capacity increases rapidly as $\mathrm{pH}$ increases from 3.5 to 5.5. However, within the range from 5.5 to 6.5 , the increase was moderate. This effect will be discussed 
below, with greater detail, from the equilibrium experiments data. The effect of $\mathrm{pH}$ on the kinetic constant shows a rapid decrease from $\mathrm{pH} 3.5$ to $\mathrm{pH} 4.5$ and then a slightly increase as $\mathrm{pH}$ is augmented. The observed dependence of the kinetic constant on the solution $\mathrm{pH}$ is rather complex. This fact also reflects the complex nature of the adsortive behavior. A tentative explanation could be found taking into account the different composition of the counterions balancing the carboxylic groups. At natural $\mathrm{pH}$ this counterions are mainly $\mathrm{Na}^{+}$, $\mathrm{K}^{+}, \mathrm{Ca}^{2+}$ and $\mathrm{Mg}^{2+}$. When $\mathrm{pH}$ decreases, protons replace these ions, whereas when $\mathrm{pH}$ increases, they are replaced by the counterion of the alkali employed, $\mathrm{Na}^{+}$in the present case. This fact makes that cadmium ions have to exchange with different ions depending on solution $\mathrm{pH}$, thus, the interaction energy may be different in each case, which would be reflected in the kinetic constant.

From these results we selected a $\mathrm{pH}$ value around 5 to determine the effect of other parameters on cadmium uptake kinetics (see below). Since the natural $\mathrm{pH}$ value of cadmiumalga solutions is contained between 5 and 5.5 for all the experimental conditions tested, no $\mathrm{pH}$ adjustment was made during the kinetics studies described below.

\section{Effect of initial metal concentration}

Experimental data points obtained for the biosorption of cadmium by Fucus spiralis at several cadmium concentrations are shown in Figure 2. Table 1 shows the constants of Equation (3) that were obtained from slope and intercept of straight line plots of $t / q_{t}$ against $t$. All the fits show very good coefficients of correlation. The equilibrium biosorption capacity, $q_{e}$ increases with an increase in the initial cadmium concentration. The values of rate constant, $k$, were found to increase for a decrease in the initial cadmium concentration. The corresponding linear plots of the values of $q_{e}$ and $k$ against $C_{i}$ were regressed to obtain expressions for these values in terms of the $C_{i}$ parameters respectively as follows: 


$$
\begin{aligned}
& \mathrm{q}_{\mathrm{e}}=(0.77 \pm 0.13) \cdot \mathrm{C}_{\mathrm{i}}^{0.81 \pm 0.03} \\
& \mathrm{k}=(1.45 \pm 0.07) \cdot \mathrm{C}_{\mathrm{i}}^{-0.93 \pm 0.02}
\end{aligned}
$$

Substituting the values of $q_{e}$ and $k$ from the equations above in Equation (3), the rate law for a pseudo-second order reaction and the relationship between $q_{t}, C_{i}$ and $t$ can be represented as:

$$
\mathrm{q}_{\mathrm{t}}=\frac{0.81 \cdot \mathrm{C}_{\mathrm{i}}^{0.69} \mathrm{t}}{1+1.12 \cdot \mathrm{C}_{\mathrm{i}}^{-0.12} \mathrm{t}}
$$

This equation can be used to derive the amount of cadmium adsorbed at any given ion concentration and reaction time as shown in Figure 2. This is related to the percentage of cadmium removed (Table1) through the following equation:

$$
\% \mathrm{Cd}_{\text {removed }}=\frac{\mathrm{q}_{\mathrm{t}} \cdot \mathrm{W}}{\mathrm{C}_{\mathrm{i}} \cdot \mathrm{V}} \times 100
$$

Good fits between predicted curves with a pseudo-second order model and the experimental data points were found. This support the idea that chemisorption is the ratelimiting step and that the mechanism follows a pseudo-second order process.

\section{Effect of alga dose}

The results of the effect of Fucus spiralis dose, $m_{s}\left(g \cdot L^{-1}\right)$, on experiments carried out using the same initial cadmium concentration $250 \mathrm{mg} \cdot \mathrm{L}^{-1}$, temperature of $25 \pm 0.1{ }^{\circ} \mathrm{C}$ and natural $\mathrm{pH}$ are shown in Figure 3. The rate constant, $k$, and the equilibrium biosorption capacity, $q_{e}$, were calculated from the intercept and slope of the straight line plots of $t / q_{t}$ against $t$ in Equation (4) and are shown in Table 1. The data showed a good compliance with the pseudo-second order model and the coefficient of correlation for the linear plots were very good. The cadmium uptake values $\left(\mathrm{q}_{\mathrm{e}}\right)$ increased with a decrease in algae mass, though this cannot be attributed to a greater biosorption capacity. In this case, the relevant parameter is 
the percentage of removed cadmium, Table 1 shows that an increase in biomass quantity, strongly affects the quantities of cadmium removed from aqueous solution. With the appropriate ratio of biomass quantity per volume of wastewater containing heavy metal, depuration levels higher than $90 \%$ can be obtained.

The corresponding linear plots of the values of $q_{e}$ and $k$ against $m_{s}$ were regressed to obtain expressions for these values in terms of the $m_{s}$ parameters respectively as follows:

$$
\begin{aligned}
& \mathrm{q}_{\mathrm{e}}=(113 \pm 3) \cdot \mathrm{m}_{\mathrm{s}}^{-0.64 \pm 0.03} \\
& \mathrm{k}=\left(0.0017 \pm 2 \cdot 10^{-4}\right) \cdot \mathrm{m}_{\mathrm{s}}^{1.75 \pm 0.07}
\end{aligned}
$$

Substituting the values of $q_{e}$ and $k$ from the equations above in Equation (3), the rate law for a pseudo-second order reaction and the relationship between $q_{t}, m_{s}$ and $t$ can be represented as:

$$
\mathrm{q}_{\mathrm{t}}=\frac{21 \cdot \mathrm{m}_{\mathrm{s}}^{0.47} \mathrm{t}}{1+0.2 \cdot \mathrm{m}_{\mathrm{s}}^{1.11} \mathrm{t}}
$$

This equation can be used to derive the amount of cadmium sorbed at any given alga dose and the reaction time as shown in Figure 3, where very good compliance with experimental data can be observed.

The opposite trend shown by the kinetic constant when the alga dose or the metal concentration are varied, can be explained in terms of the ratio algal sites/metal concentration. The kinetic constant increases as the proportion of the complexation sites, directly related to the alga dose, to the metal concentration is increased, which occurs both when the alga dose is augmented and when the metal concentration is decreased. The effect is probably due to the presence of this ratio in the pseudo-second order constant. Nevertheless, this hypothesis cannot be demonstrated because, unfortunatly, there is no rigurous theoretical demonstration of the pseudo-second order equation, which would lead to an interpretation of the kinetic constant. 


\section{Effect of temperature}

The temperature dependence of cadmium biosorption by Fucus spiralis was studied with an initial cadmium concentration of $250 \mathrm{mg} \cdot \mathrm{L}^{-1}$, alga dose of $2.5 \mathrm{~g} \cdot \mathrm{L}^{-1}$ and natural $\mathrm{pH}$. The experimental points show a good compliance with the pseudo-second order equation, which are reflected by the high coefficients of correlation obtained. Fitting parameters according to Equation (3) are shown in Table 1.

The equilibrium biosorption capacity, $q_{e}$, increases slightly with temperature and the rate constant, $k$, also increases with an augment in the temperature. The increase in the equilibrium biosorption capacity and in the rate constant seems to indicate that a high temperature favors cadmium removal. However, the effect of temperature is really small and variations in the range $15-45^{\circ} \mathrm{C}$ did not produce any significant differences in cadmium biosorption. In fact, the necessary time to reach equilibrium for the different temperatures studied is practically the same and, as can be observed from Table 1 , in this range of temperature the percentage of cadmium removed from solution increase only in a $6 \%$. Figure 4 shows a linear relationship between the log of rate constant and the reciprocal of Kelvin temperature. The activation energy for the biosorption of cadmium by Fucus spiralis was calculated using the Arrhenius equation:

$$
\mathrm{k}=\mathrm{k}_{\mathrm{o}} \cdot \exp \left(\frac{-\mathrm{E}}{\mathrm{R} \cdot \mathrm{T}}\right)
$$

where $k\left(\mathrm{~g} \cdot \mathrm{mg}^{-1} \cdot \mathrm{min}^{-1}\right)$ is the pseudo-second order constant of sorption, $k_{o}$ is the temperature independent factor $\left(\mathrm{g} \cdot \mathrm{mg}^{-1} \cdot \mathrm{min}^{-1}\right), E$ is the activation energy of sorption $\left(\mathrm{kJ} \cdot \mathrm{mol}^{-1}\right), R$ is the gas constant $\left(8.314 \mathrm{~J} \cdot \mathrm{mol}^{-1} \cdot \mathrm{K}^{-1}\right)$ and $T$ is the solution temperature $(\mathrm{K})$. The activation energy and the temperature independent factor for the biosorption of cadmium by Fucus spiralis have been determined to be $12.3 \mathrm{~kJ} \cdot \mathrm{mol}^{-1}$ and $1.01 \mathrm{~g} \cdot \mathrm{mg}^{-1} \cdot \mathrm{min}^{-1}$, respectively. 
According to the literature, there is not a clear effect of the temperature on the biosorption process for different metal-biomaterials systems. Different and opposite behaviors can be found. Martins, ${ }^{[16]} \mathrm{Aksu}^{[17]}{ }^{\mathrm{Ajmal}}{ }^{[18]}$ reported higher uptake capacities in different organisms at increased temperature. On the other hand, Ahuja, ${ }^{[19]}$ Martins, ${ }^{[16]}$ de Rome, ${ }^{[20]}$ $\mathrm{Aksu}^{[21]}$ found a practically temperature independent biosorption process. In contrast, $\mathrm{Cruz}^{[22]}$ and $\mathrm{Aksu}^{[23]}$ found a decrease in the biosorption capacity with an increase in temperature. Even a more complex situation was described by Benguella and Benaissa ${ }^{[24]}$ for the adsorption of cadmium by chitin where an initial increase in the capacity of sorption was followed by a subsequent reduction.

\section{Acid-base properties of Fucus spiralis}

The number of carboxyl groups per gram of alga $\left([\mathrm{COOH}]_{t o t a l}\left(\mathrm{mmol} \cdot \mathrm{g}^{-1}\right)\right)$ was calculated from the volume at the equivalence point $\left(V_{e q}\right)$ of the potentiometric titration curve for protonated Fucus spiralis (Figure 5), using the following equation:

$$
[\mathrm{COOH}]_{\text {total }}=\frac{\mathrm{V}_{\text {eq }} \cdot[\mathrm{NaOH}]}{\mathrm{w}}
$$

W

The total number of acid groups is $2.90 \mathrm{mmol} \cdot \mathrm{g}^{-1}$ for Fucus spiralis. Similar values were obtained for other marine algae. ${ }^{[25]}$

Katchalsky $^{[26]}$ found that the titration curve of a polyacid could be empirically described by two constants, $p K$ and $n$, according to the following equation:

$$
\mathrm{pH}=\mathrm{pK}-\mathrm{n} \cdot \log \frac{1-\alpha}{\alpha}
$$

where $\alpha$ represents the degree of dissociation that is defined in Equation (13) and $n$ is an empirical parameter, whose value is greater but close to one, 


$$
\alpha=\frac{\left[\mathrm{COO}^{-}\right]}{\left(\mathrm{C}_{\mathrm{o}} \cdot \mathrm{V}_{\mathrm{o}}\right) /\left(\mathrm{V}_{\mathrm{o}}+\mathrm{V}_{\mathrm{NaOH}}\right)}
$$

where $V_{\mathrm{NaOH}}$ is the volume of $\mathrm{NaOH}$ added and $C_{\mathrm{o}}$ is the initial concentration of the carboxylic acid, calculated from an equation formally identical to Equation (11) but referred to the volume of solution, where now $V_{o}$, the initial volume, substitutes w. The concentration of deionized carboxylate groups, [ $\left.\mathrm{COO}^{-}\right]$, was calculated from the base additions by means of charge balance considerations:

$$
\left[\mathrm{COO}^{-}\right]=\left[\mathrm{H}^{+}\right]+\frac{\mathrm{V}_{\mathrm{NaOH}} \cdot[\mathrm{NaOH}]}{\left(\mathrm{V}_{\mathrm{o}}+\mathrm{V}_{\mathrm{NaOH}}\right)}-\frac{\mathrm{K}_{\mathrm{w}}}{\left[\mathrm{H}^{+}\right]}
$$

From slope and intercept of straight line plots of $p H$ against $\log ((1-\alpha) / \alpha)$ according Equation (12), $p K$ and $n$ values were experimentally determined. Figure 6 shows these values and the fit of experimental data points to Equation (12) with its coefficient of correlation, $r^{2}$.

The $p K$ value obtained, 3.49 , is in good agreement with the values corresponding to carboxyl groups from mannuronic and guluronic acids (3.38 and 3.65) of alginate ${ }^{[27]}$ or the value for alginic acid. ${ }^{[28]}$ Therefore, these groups are likely to be responsible for cadmium sorption.

\section{Adsorption equilibrium}

\section{Effect of $p H$ on metal uptake}

The biosorption capacity of the alga strongly depends on equilibrium solution $\mathrm{pH}$ so characterization of the $\mathrm{pH}$ effect on adsorption equilibrium is necessary for an accurate evaluation of equilibrium parameters.

The effect of solution $\mathrm{pH}$ on cadmium biosorption by biomass of Fucus spiralis was studied and it is showed in Figure 7. From Figure 7, it is seen that there is a fast increase in cadmium uptake with increasing $\mathrm{pH}$ from 1.0 to 4.0 , while around $\mathrm{pH} 4.5$, the cadmium 
biosorption capacity levels off at a maximum value reaching a plateau. However, at $\mathrm{pH}$ lower than 2 , the cadmium uptake capacity is almost negligible. At $\mathrm{pH}$ values higher than 8 , several hydroxyl low-soluble species can be formed, i.e. $\mathrm{Cd}(\mathrm{OH})_{2}$ and $\mathrm{Cd}(\mathrm{OH})_{3}{ }^{-}$. The speciation of cadmium ion was obtained by means of MINEQL+ programme ${ }^{[29]}$ which showed that free cadmium ion was the only specie formed in the $\mathrm{pH}$ interval studied ${ }^{[30]}$ (between 3.5 and 6.5). Equilibrium experiments were carried out at $\mathrm{pH} 4.5$, where the maximum uptake capacity was achieved and cadmium precipitation was avoided.

The $\mathrm{pH}$ dependence on cadmium uptake is closely related to the ionic state of cell wall functional groups, mainly carboxyl, as well as the cadmium speciation in solution. It can well be assumed that cadmium is present in its free ionic form, $\mathrm{Cd}^{+2}$, at $\mathrm{pH}$ values lower than 8.0. This implies that the type and ionic state of the carboxyl functional groups with a $\mathrm{pK}_{\mathrm{a}}$ value around 3.5 (Figure 6) determine the cadmium biosorption in the $\mathrm{pH}$ range studied. At $\mathrm{pH}$ values lower than $\mathrm{pK}_{\mathrm{a}}$, carboxylate groups are closely associated with the hydrogen ions, restricting access to sites by cadmium ions as a result of repulsive forces and resulting in a low cadmium uptake. This effect is stronger at lower $\mathrm{pH}$. At $\mathrm{pH}$ values higher than $\mathrm{pK}_{\mathrm{a}}$, more carboxylate groups carry negative charge and the positively charged cadmium ions will be bound, reducing the electrostatic repulsion and increasing the cadmium uptake. A physicochemical realistic model to account for the effects of $\mathrm{pH}$ and ionic strength in proton binding equilibria of algae was recently proposed by Rey-Castro et al. ${ }^{[25]}$ The proton binding active zone of the algal biomass is supposed to be constituted of a polyelectrolyte that forms a charged, three-dimensional structure. Moreover, surface charge models reproduced with similar accuracy experimental equilibrium data. ${ }^{[31]}$ 
The adsorption of a substance from one phase to the surface of another in a specific system leads to a thermodynamically defined distribution of that substance between the phases as the system reaches equilibrium. This distribution can be expressed in terms of adsorption isotherms. ${ }^{[32]}$ Table 2 shows the different adsorption isotherm equations used in this work to fit experimental data points. These models use parameters which reflect the nature of the sorbent and can be used to compare the biosorption performance, $q_{\max }$ represents the maximum metal adsorption and $b$ is an affinity parameter; a high value of parameter $b$ indicates a steep desirable beginning of the isotherm reflecting the high affinity of the biosorbent for the sorbate; $\mathrm{k}_{f}$ relates to biosorption capacity and $n$ is an empirical parameter, which varies with the degree of heterogeneity.

The experimental data points fitted to Langmuir, Freundlich, Langmuir-Freundlich and Tóth isotherm equations for cadmium biosorption by Fucus spiralis at a solution $\mathrm{pH}$ of $4.5 \pm 0.1$ are shown in Figure 8. The metal uptake $\left(q_{e}\right)$ values are calculated by using Equation (2). The adjustable parameters $\left(q_{\max }, b, k_{F}\right.$ and $\left.n\right)$ obtained are listed in Table 2 . The two most used equilibrium adsorption isotherm models in the literature are the Langmuir and Freundlich isotherms. Langmuir model exhibits lower errors and better fits than Freundlich model. According to the coefficients of correlation obtained and the fit showed in Figure 8, the Freundlich isotherm is not adequate for modeling the removal of cadmium by Fucus spiralis. Langmuir, Langmuir-Freundlich and Tóth model present similar and good fits of the experimental data (Table 2 and Figure 8), so all of them are adequate for modeling the isotherm of sorption. However, Langmuir model implies only two fitting parameters, while, both Langmuir-Freundlich and Tóth models require three parameters. This fact makes Langmuir model to be easier to employ because it can be linearized. The applicability of these models should be considered as a mathematical representation of the sorption equilibrium over a given metal concentration range which can provide information on metal-uptake 
capacities. The application of these models to complex biological system such as marine algae may not be able to explain the biosorption behavior, so mechanistic conclusions supported only from the good fit of the models should be avoided. ${ }^{[33]}$

Table 3 shows a comparison of the maximum cadmium uptake biosorption $\left(q_{\max }\right)$ by Fucus spiralis with different adsorbents found in literature. As it can be seen the biosorption capacity of Fucus spiralis is similar to those obtained by other marine algae and considerably higher than the exhibited by many of the adsorbents commonly used in many practical metal recovery applications. More extensive compilations of the adsorption of metals by different biosorbent materials can be found in the literature. ${ }^{[1,2,4,34]}$

\section{CONCLUSIONS}

The kinetics of cadmium biosorption by Fucus spiralis is relatively rapid with $90 \%$ of total biosorption occurring in less than one hour. This process can be described by a pseudosecond order model based on the assumption that the rate limiting step may be chemical sorption or chemisorption. The biosorption equilibrium capacity is a function of initial cadmium concentration, alga dose and $\mathrm{pH}$ of the solution, whereas temperature has a negligible effect on the biosorption. The activation energy of sorption can be evaluated using the pseudo-second order rate constants.

This work indicates that Fucus spiralis can be used for the removal of cadmium from wastewaters with a biosorption capacity comparable or higher than other commercial materials. A Langmuir isotherm model can be used to estimate the maximum cadmium uptake and the affinity parameter that reflects the affinity of the material for the solute.

Solution $\mathrm{pH}$ is an important parameter affecting biosorption of cadmium by Fucus spiralis, being the biosorption capacity almost negligible at $\mathrm{pH} \leq 2.0$ and reaching a plateau at 
around 4.0. This behavior is very useful to perform adsorption/desorption cycles, an important step in order to develop columns with biomass as adsorbing agent.

Potentiometric titrations allow to calculate the number of carboxyl groups, and the $\mathrm{pK}$ by use of Katchalsky model. These values agree with the $\mathrm{pK}$ corresponding to carboxyl groups from alginate, which are likely to be responsible for cadmium biosorption.

\section{ACKNOWLEDGMENTS}

The authors wish to thank Xunta de Galicia through project PGIDT02TAM10302PR and Ministerio de Ciencia y Tecnología through project BQU 2002-02133 for financial support. The authors would like to thank Dr. I. Bárbara and Dr. J. Cremades (U. of A Coruña) for the collection and classification of the alga.

\section{REFERENCES}

[1] B. Volesky, Biosorption of heavy metals 1990, (CRC Press:Boca Raton, Flo.).

[2] J. Wase, C.F. Forster, Biosorbents for metal ions 1997, (Taylor \& Francis:London).

[3] B. Volesky, Hydrometallurgy 2001, 59, 203.

[4] S.E. Bailey, T.J. Olin, R.M. Bricka, D.D. Adrian, Wat. Res. 1999, 33, 2469.

[5] R.H. Crist, K. Oberholser, N. Shank, M. Nguyen, Environ. Sci. Technol. 1981, 15, 1212.

[6] T.A. Davis, B. Volesky, A. Mucci, Wat. Res. 2003, 37, 4311.

[7] E. Percival, R.H. McDowell, Chemistry and enzymology of marine algal polysaccharides 1967, (Academic Press:London New York).

[8] R.H. Crist, J.R. Martin, P.W. Guptill, J.M. Eslinger, D.R. Crist, Environ. Sci. Technol. $1990,24,337$. 
[9] C. Aharoni, D.L. Sparks, in Rates of soil chemical processes (Eds Sparks DL, Suárez

DL) 1991, pp. 1 (Soil Science Society of America: Madison (WI))

[10] Y.S. Ho, D.A.J. Wase, C.F. Forster, Environ. Technol. 1996, 17, 71.

[11] Y.S. Ho, G. McKay, Wat. Res. 2000, 34, 735.

[12] I. Brandariz, T. Vilariño, P. Alonso, R. Herrero, S. Fiol, M.E. Sastre de Vicente, Talanta 1998, 46, 1469.

[13] S. Fiol, F. Arce, X.L. Armesto, F. Penedo, M.E. Sastre de Vicente, Fresenius J. Anal. Chem. 1992, 343, 469.

[14] Y.S. Ho, G. McKay, Process Biochem. 1999, 34, 451.

[15] Y.S. Ho, Wat. Res. 2003, 37, 2323.

[16] R.J.E. Martins, R. Pardo, R.A.R. Boaventura, Wat. Res. 2004, 38, 693.

[17] Z. Aksu, T. Kutsal, J.Chem.Tech.Biotechnol. 1991, 52, 109.

[18] M. Ajmal, R.A.K. Rao, S. Anwar, J. Ahmad, R. Ahmad, Bioresour. Technol. 2003, 86, 147.

[19] P. Ahuja, R. Gupta, R.K. Saxena, Process Biochem. 1999, 34, 77.

[20] L. de Rome, G.M. Gadd, Appl. Microbiol. Biotechnol. 1987, 26, 84.

[21] Z. Aksu, T. Kutsal, Environ. Technol. 1990, 11, 979.

[22] C.C.V. Cruz, A.C.A. Costa, C.A. Henriques, A.S. Luna, Bioresour. Technol. 2004, 91, 249.

[23] Z. Aksu, Sep. Purif. Technol. 2001, 21, 285.

[24] B. Benguella, H. Benaissa, Wat. Res. 2002, 36, 2463.

[25] C. Rey-Castro, P. Lodeiro, R. Herrero, M.E. Sastre de Vicente, Environ. Sci. Technol. 2003, 37, 5159 .

[26] A. Katchalsky, N. Shavit, H. Eisenberg, J. Polymer. Sci. 1954, 13, 69.

[27] A. Haug, Acta Chem. Scand. 1961, 15, 950. 
[28] C. Rey-Castro, R. Herrero, M.E. Sastre de Vicente, J. Electroanal. Chem. 2004, 564, 223.

[29] W.D. Schecher, D.C. McAvoy, Computers, Environment and Urban Systems 1992, 16.

[30] P. Lodeiro, B. Cordero, Z. Grille, R. Herrero, M.E. Sastre de Vicente, Biotechnol. Bioeng. 2004, 88, 237.

[31] C. Rey-Castro, R. Herrero, M.E. Sastre de Vicente, Chem. Spec. Bioavail. 2004, 16, 61.

[32] D.G. Kinniburgh, Environ. Sci. Technol. 1986, 20, 895.

[33] A. Kapoor, T. Viraraghavan, Bioresour. Technol. 1995, 53, 195.

[34] F. Vegliò, F. Beolchini, Hydrometallurgy 1997, 44, 301.

[35] Z.R. Holan, B. Volesky, I. Prasetyo, Biotechnol. Bioeng. 1993, 41, 819.

[36] Y.S. Ho, C.C. Wang, Process Biochem. 2004, 39, 759.

[37] J.T. Matheickal, Q. Yu, G.M. Woodburn, Wat. Res. 1999, 33, 335.

[38] Z.R. Holan, B. Volesky, Appl.Biochem.Biothechnol. 1995, 53, 133.

[39] E. Fourest, C. Canal, J.-C. Roux, FEMS Mibrobiology Reviews 1994, 14, 325.

[40] S. Chamarthy, C.W. Seo, W.E. Marshall, J.Chem.Tech.Biotechnol. 2001, 76, 593. 
Table 1. Kinetic parameters of cadmium uptake by Fucus spiralis at several solution $\mathrm{pH}$, initial concentrations, alga dose and temperature. The percentage of $\mathrm{Cd}$ removed from solution at the end of the kinetic process is also included (equation (7)).

\begin{tabular}{|c|c|c|c|c|}
\hline $\mathbf{p H}$ & $\%$ Cd removed & $q_{e}\left(m g g g^{-1}\right)$ & $\mathrm{k}\left(\mathrm{g} \cdot \mathrm{mg}^{-1} \mathrm{~min}^{-1}\right)$ & $\mathbf{r}^{2}$ \\
\hline 3.5 & 50.2 & $50.2 \pm 0.1$ & $24 \cdot 10^{-3} \pm 2 \cdot 10^{-3}$ & 0.9999 \\
\hline 4 & 55.8 & $55.75 \pm 0.06$ & $9.0 \cdot 10^{-3} \pm 0.3 \cdot 10^{-3}$ & 0.9999 \\
\hline 4.5 & 62.6 & $62.60 \pm 0.04$ & $5.8 \cdot 10^{-3} \pm 0.1 \cdot 10^{-3}$ & 0.9999 \\
\hline 5 & 65.9 & $65.94 \pm 0.05$ & $5.5 \cdot 10^{-3} \pm 0.1 \cdot 10^{-3}$ & 0.9999 \\
\hline 5.5 & 69.3 & $69.26 \pm 0.06$ & $5.7 \cdot 10^{-3} \pm 0.1 \cdot 10^{-3}$ & 0.9999 \\
\hline 6 & 70.4 & $70.38 \pm 0.05$ & $6.9 \cdot 10^{-3} \pm 0.2 \cdot 10^{-3}$ & 0.9999 \\
\hline 6.5 & 76.6 & $71.58 \pm 0.07$ & $7.3 \cdot 10^{-3} \pm 0.2 \cdot 10^{-3}$ & 0.9999 \\
\hline$C_{i}\left(m g \cdot L^{-1}\right)$ & $\% \mathrm{Cd}$ removed & $q_{e}\left(m g \cdot g^{-1}\right)$ & $\mathrm{k}\left(\mathrm{g} \cdot \mathrm{mg}^{-1} \mathrm{~min}^{-1}\right)$ & $\mathbf{r}^{2}$ \\
\hline 10 & 91.2 & $3.646 \pm 0.003$ & $171 \cdot 10^{-3} \pm 6 \cdot 10^{-3}$ & 0.9999 \\
\hline 50 & 88.0 & $17.60 \pm 0.02$ & $40 \cdot 10^{-3} \pm 2 \cdot 10^{-3}$ & 0.9999 \\
\hline 100 & 82.1 & $32.83 \pm 0.03$ & $19.0 \cdot 10^{-3} \pm 0.6 \cdot 10^{-3}$ & 0.9999 \\
\hline 250 & 65.9 & $65.9 \pm 0.1$ & $7.4 \cdot 10^{-3} \pm 0.4 \cdot 10^{-3}$ & 0.9999 \\
\hline$m_{s}\left(\right.$ g alga $\left.\cdot L^{-1}\right)$ & \%Cd removed & $q_{e}\left(m g \cdot g^{-1}\right)$ & $\mathrm{k}\left(\mathrm{g} \cdot \mathrm{mg}^{-1} \mathrm{~min}^{-1}\right)$ & $\mathbf{r}^{2}$ \\
\hline 1 & 44.9 & $112.3 \pm 0.3$ & $1.93 \cdot 10^{-3} \pm 0.07 \cdot 10^{-3}$ & 0.9998 \\
\hline 2.5 & 65.9 & $65.9 \pm 0.1$ & $7.4 \cdot 10^{-3} \pm 0.4 \cdot 10^{-3}$ & 0.9999 \\
\hline 5 & 82.3 & $41.17 \pm 0.03$ & $25 \cdot 10^{-3} \pm 3 \cdot 10^{-3}$ & 0.9999 \\
\hline 10 & 91.6 & $22.91 \pm 0.01$ & $124 \cdot 10^{-3} \pm 10 \cdot 10^{-3}$ & 1.0000 \\
\hline $\mathbf{T}(\mathbf{K})$ & $\% \mathrm{Cd}$ removed & $q_{e}\left(m g \cdot g^{-1}\right)$ & $k\left(g \cdot \mathrm{mg}^{-1} \min ^{-1}\right)$ & $\mathbf{r}^{2}$ \\
\hline 288 & 65.6 & $65.6 \pm 0.1$ & $5.8 \cdot 10^{-3} \pm 0.3 \cdot 10^{-3}$ & 0.9998 \\
\hline 298 & 65.9 & $65.9 \pm 0.1$ & $7.4 \cdot 10^{-3} \pm 0.4 \cdot 10^{-3}$ & 0.9999 \\
\hline 308 & 70.4 & $70.37 \pm 0.03$ & $8.4 \cdot 10^{-3} \pm 0.1 \cdot 10^{-3}$ & 1.0000 \\
\hline 318 & 71.7 & $71.72 \pm 0.02$ & $9.5 \cdot 10^{-3} \pm 0.1 \cdot 10^{-3}$ & 1.0000 \\
\hline
\end{tabular}


Table 2. Adsorption isotherm equations and the corresponding parameters for cadmium biosorption by Fucus spiralis at $\mathrm{pH} 4.5 \pm 0.1$.

\begin{tabular}{llllll}
\hline Model & Equation & $\boldsymbol{q}_{\max }\left(\mathbf{m g} \cdot \mathbf{g}^{-1}\right)$ & $\boldsymbol{b}\left(\mathbf{L} \cdot \mathbf{m g}^{-1}\right) / \boldsymbol{k}_{F}$ & $\boldsymbol{n}$ & $\mathbf{r}^{2}$ \\
\hline Langmuir & $\mathrm{q}_{\mathrm{e}}=\frac{\mathrm{q}_{\max } \cdot \mathrm{b} \cdot \mathrm{C}}{1+\mathrm{b} \cdot \mathrm{C}}$ & $64 \pm 2$ & $0.053 \pm 0.005$ & 0.9958 \\
Freundlich & $\mathrm{q}_{\mathrm{e}}=\mathrm{k}_{\mathrm{F}} \cdot \mathrm{C}^{1 / \mathrm{n}}$ & & $10 \pm 3$ & $2.85 \pm 0.49$ & 0.9122 \\
Langmuir- & $\mathrm{q}_{\mathrm{e}}=\frac{\mathrm{q}_{\max } \cdot(\mathrm{b} \cdot \mathrm{C})^{1 / \mathrm{n}}}{1+(\mathrm{b} \cdot \mathrm{C})^{1 / \mathrm{n}}}$ & & & & \\
Freundlich & & & $0.06 \pm 0.01$ & $0.87 \pm 0.07$ & 0.9974 \\
Tóth & $\mathrm{q}_{\mathrm{e}}=\frac{\mathrm{q}_{\max } \cdot \mathrm{b} \cdot \mathrm{C}}{\left[1+(\mathrm{b} \cdot \mathrm{C})^{1 / \mathrm{n}}\right]^{\mathrm{n}}}$ & $60 \pm 2$ & $0.05 \pm 0.01$ & $0.77 \pm 0.12$ & 0.9974 \\
\hline
\end{tabular}


Table 3. Comparison of the maximum cadmium uptake capacities of various adsorbents.

\begin{tabular}{|c|c|c|}
\hline Adsorbent & $q_{\max }\left(m g \cdot g^{-1}\right)$ & Reference \\
\hline Fucus spiralis (brown marine alga) & 64 & This work \\
\hline Sargassum filipendula (brown marine alga) & 74 & [6] \\
\hline \multirow[t]{2}{*}{ Sargassum muticum (brown marine alga) } & 76 & [6] \\
\hline & 65 & [30] \\
\hline Sargassum fluitans (brown marine alga) & 80 & [6] \\
\hline Sargassum vulgare (brown marine alga) & 89 & {$[6]$} \\
\hline Fucus vesiculosus (brown marine alga) & 73 & [35] \\
\hline Sargassum sp. (brown marine alga) & 120 & [22] \\
\hline Chlorella vulgaris (green microalga) & 111 & [23] \\
\hline Fontinalis antipyretica (aquatic moss) & 28 & [16] \\
\hline Tree fern & 16 & [36] \\
\hline Pseudomonas aeruginosa (yeast) & 43 & [37] \\
\hline Chitin & 14 & [24] \\
\hline \multirow[t]{2}{*}{ Rhizopus arrhizus (fungus) } & 30 & [38] \\
\hline & 27 & [39] \\
\hline \multirow[t]{2}{*}{ Penicillium chrysogenum (fungus) } & 56 & [38] \\
\hline & 44 & [39] \\
\hline Absidia orchidis (fungus) & 31 & [38] \\
\hline Rhizopus nigricans (fungus) & 19 & [38] \\
\hline Granulated activated carbon & 8 & [37] \\
\hline $\mathrm{Fe}(\mathrm{III}) / \mathrm{Cr}(\mathrm{III})$ hydroxide & 47 & [37] \\
\hline Peat moss & 22 & [37] \\
\hline \multirow[t]{2}{*}{ Duolite GT-73 } & 67 & [35] \\
\hline & 55 & [40] \\
\hline Amberlite IRA-400 & 56 & [35] \\
\hline Amberlite IRC-718 & 202 & [40] \\
\hline Amberlite 200 & 143 & [40] \\
\hline Clinotiloite & 24 & [37] \\
\hline Carboxymethylcellulose & 69 & [40] \\
\hline
\end{tabular}




\section{Figure captions}

Figure 1: Kinetics of cadmium uptake by Fucus spiralis at several solution $\mathrm{pH}$ values. Lines represent modeled results using the pseudo-second order model, Equation (3), at temperature of $25 \pm 0.1^{\circ} \mathrm{C}$, initial cadmium concentration $250 \mathrm{mg} \cdot \mathrm{L}^{-1}$ and alga dose $2.5 \mathrm{~g} \cdot \mathrm{L}^{-1}$.

Figure 2: Kinetics of cadmium uptake by Fucus spiralis at several initial concentrations, temperature of $25.0 \pm 0.1{ }^{\circ} \mathrm{C}$, alga dose $2.5 \mathrm{~g} \cdot \mathrm{L}^{-1}$ and natural $\mathrm{pH}$. Lines represent modeled results calculated using Equation (6)

Figure 3: Kinetics of cadmium uptake by Fucus spiralis at several alga dose, temperature of $25.0 \pm 0.1{ }^{\circ} \mathrm{C}$, initial cadmium concentration $250 \mathrm{mg} \cdot \mathrm{L}^{-1}$ and natural $\mathrm{pH}$. Lines represent modeled results calculated using Equation (9).

Figure 4: Plot of $\ln (k)$ against reciprocal temperature for cadmium biosorption by Fucus spiralis.

Figure 5: Titration curve ( $\mathrm{pH}$ vs. $\mathrm{NaOH}$ volume) for $0.5 \mathrm{~g}$ of Fucus spiralis with ionic strength adjusted to $0.05 \mathrm{M}$ with $\mathrm{NaNO}_{3}$. The squares represent experimental data points and the solid line the derivative of the experimental curve.

Figure 6: Katchalsky model for Fucus spiralis at temperature of $25 \pm 0.1{ }^{\circ} \mathrm{C}$, alga dose $5 \mathrm{~g} \cdot \mathrm{L}^{-}$ ${ }^{1}$ and ionic strength $0.05 \mathrm{M}\left(\mathrm{NaNO}_{3}\right)$.

Figure 7: Effect of $\mathrm{pH}$ on cadmium biosorption by Fucus spiralis (alga dose: $2.5 \mathrm{~g} \cdot \mathrm{L}^{-1}$; initial cadmium concentration: $250 \mathrm{mg} \cdot \mathrm{L}^{-1}$; temperature: $25.0 \pm 0.1{ }^{\circ} \mathrm{C}$ ).

Figure 8: Fit of isotherms given in Table 2 for cadmium biosorption by Fucus spiralis (alga dose: $2.5 \mathrm{~g} \cdot \mathrm{L}^{-1}$; equilibrium $\mathrm{pH}: 4.5 \pm 0.1$; temperature: $25.0 \pm 0.1{ }^{\circ} \mathrm{C}$ ). 


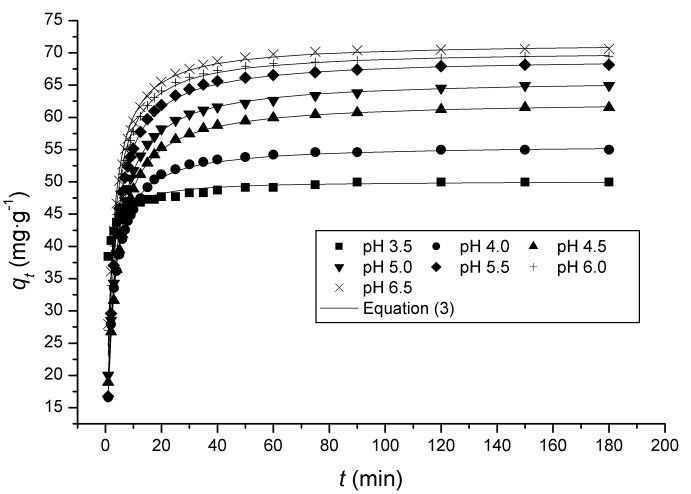

Figure 1

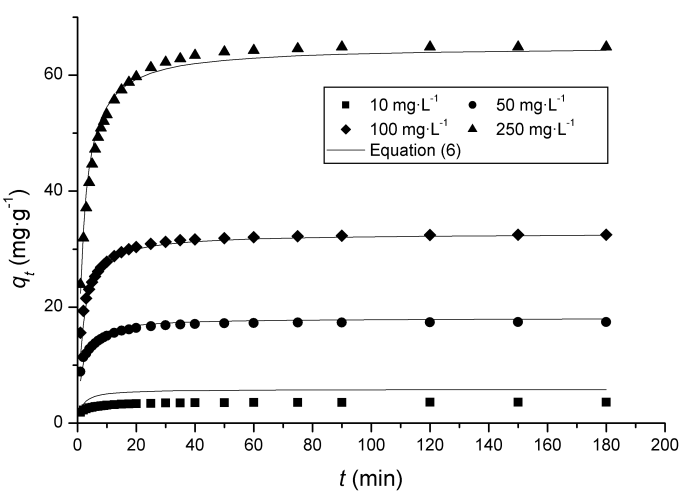

Figure 2

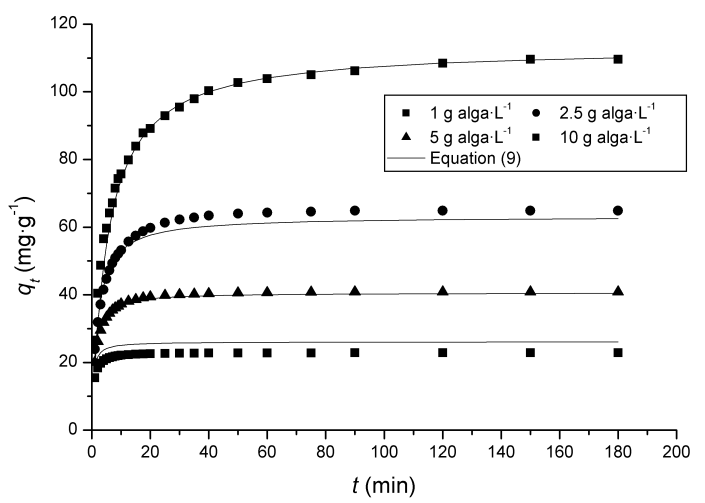

Figure 3 


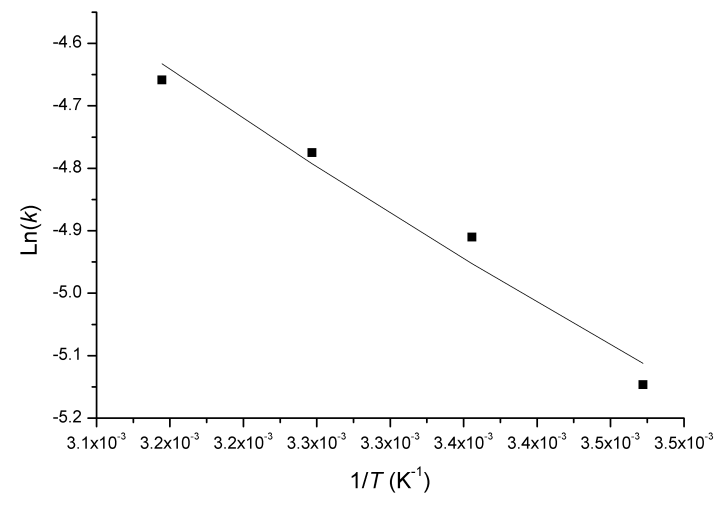

Figure 4

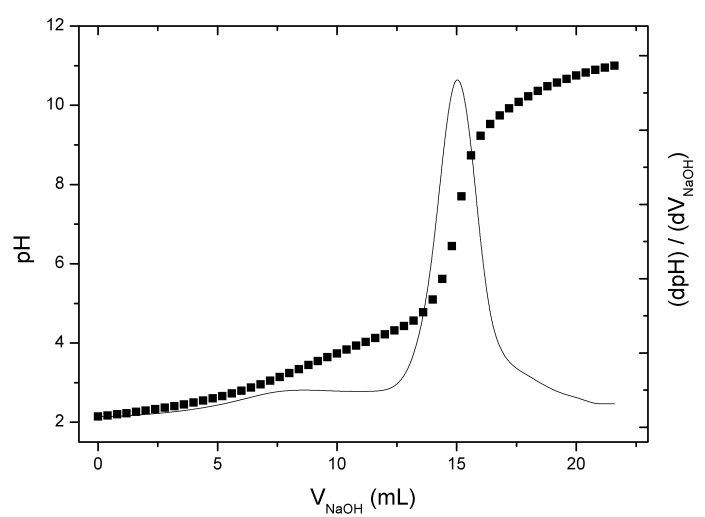

Figure 5

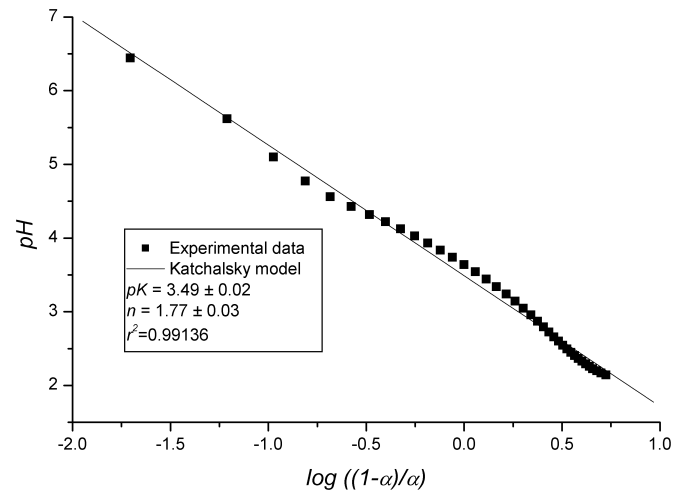

Figure 6 


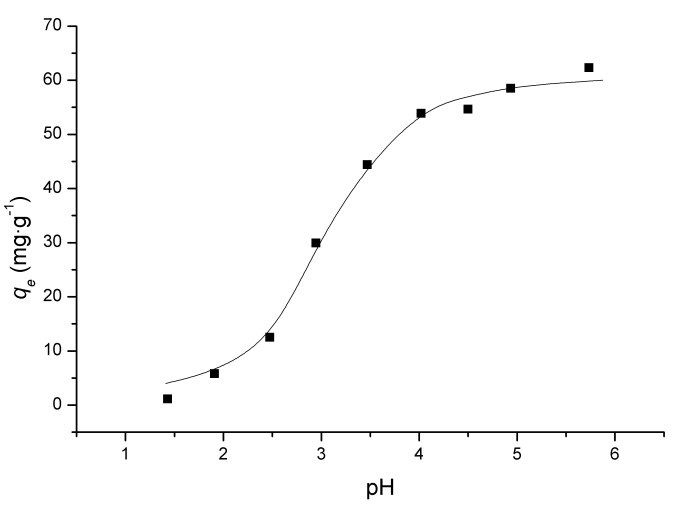

Figure 7

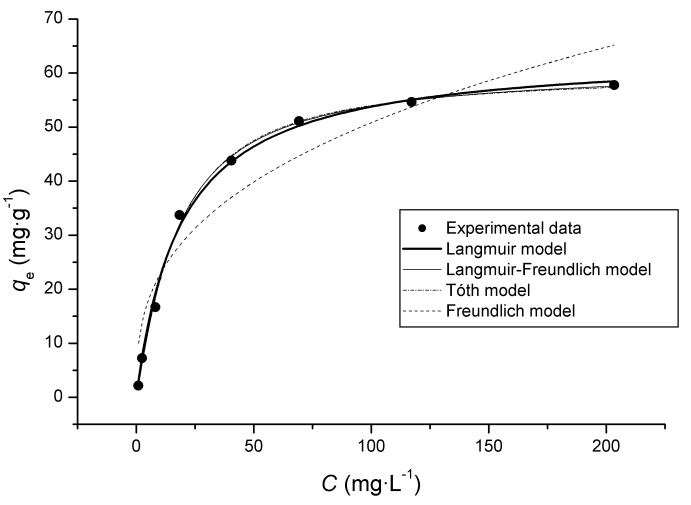

Figure 8 